\title{
Settlement and early post-settlement survival of sessile marine invertebrates on topographically complex surfaces: the importance of refuge dimensions and adult morphology*
}

\author{
Linda J. Walters ${ }^{1, * *}$, David S. Wethey ${ }^{1,2}$ \\ ${ }^{1}$ Department of Biological Sciences and ${ }^{2}$ Marine Science Program, University of South Carolina, Columbia, \\ South Carolina 29208, USA
}

\begin{abstract}
We predicted that both refuge dimension and growth form would influence settlement and short-term post-settlement success $(\leq 7 \mathrm{~d})$ of sessile marine invertebrates that live attached to hard substrata in low energy environments. Individuals with unlimited attachment to the substrata should rapidly be protected by their growth form, thus decreasing their need to settle in refuges and limiting the length of time any locations on heterogeneous substrata act as refuges. Alternatively, organisms with limited attachment to the substrata should remain susceptible to the causes of mortality for a longer time, and as a result should settle in high quality refuges (sites that protect individuals from competitors, predators or physical disturbance events until either a size refuge or reproductive maturity is obtained). Results agreed with these predictions for 4 species of invertebrates examined on both the topographically complex surface of the solitary ascidian Styela plicata (hereafter Styela) and on settlement plates with uniformly spaced roughness elements that mimicked the heights of roughness elements (2.0 and $5.0 \mathrm{~mm}$ ) found on Styela in Beaufort, North Carolina, USA. On all surfaces, the 2 species with limited attachment to the substrata, Balanus sp. (aclonal, solitary) and Bugula neritina (clonal, arborescent), settled almost exclusively in the location that provided individuals with the best refuge: the crevices formed where the bases of roughness elements intersect with the flat surfaces. Additionally, when roughness elements of various heights were present (Styela, range: 0.6 to $8.8 \mathrm{~mm}$ ), intermediate size roughness elements $(2.0<x \leq 5.0 \mathrm{~mm})$ were picked over $72 \%$ of the time. Settlement locations and locations where survival were enhanced were less consistent for the 2 species with unlimited attachment to the substrata: a clonal, encrusting form (Schizoporella errata) and a clonal stolon-mat form (Tubularia crocea). Fewer individuals of these 2 species settled on roughness elements on Styela and when they did, they were not restricted to the bases of the roughness elements. On the plate surfaces, most settlement did occur in crevices, but both species grew away from this location within days and short-term survival was not consistently greater in this location. Additional trials were run on plates with pits of the same maximum dimensions as the tested roughness elements $(2.0$ and $5.0 \mathrm{~mm}$ depth) to see if crevices and pits provide refuges of equal quality for newly settled individuals. Only survival of Balanus sp. recruits was greatest in both crevices and pits. Evidence for active choice of settlement location comes from consistent results in trials in which some larvae settled in greater numbers on specific size roughness elements on Styela and in areas of high erosion. Overall, these results show that one must be very cautious when generalizing about refuge quality on heterogeneous surfaces, and to determine if a location is a spatial refuge, it is critical to consider: (1) the dimensions of the larva, (2) the relative dimensions of the individual and potential refuge location at any point in time from the moment settlement occurred, and (3) the growth form of the individual which is related to its need for protection from biotic and abiotic sources of mortality.
\end{abstract}

KEY WORDS: Larval ecology · Settlement - Refuges - Surface heterogeneity · Fouling community

- Dedicated to the memory of Dr. John P. Sutherland, $1942-1993$
-Present address: GIROQ, Université Laval, Pavillon Vachon, Ste-Foy, Québec, Canada G1K 7P4 


\section{INTRODUCTION}

In marine habitats, many organisms persist in spite of the existence of biotic and abiotic sources of mortality. Survival of many of these organisms is dependent on refuge exploitation (reviews: Woodin 1978, Barry \& Dayton 1991). Refuges have been shown to reduce catastrophic loss to competitors (e.g. Woodin 1974, Buss 1979, Grosberg 1981, Walters \& Wethey 1986), predators (e.g. Menge \& Lubchenco 1981, Woodin 1981, Keough \& Downes 1982, Young 1986, Walters 1992a) and physical disturbance events (e.g. Connell 1961, Bergeron \& Bourget 1986, Shanks \& Wright 1986, Brawley \& Johnson 1991). If a sessile organism is unable to significantly reduce or eliminate mortality in time (temporal refuge) (e.g. Lubchenco \& Cubit 1980 , Hay et al. 1988), then a spatial refuge may provide the individual with its only chance for survival. On a broad spatial scale $(\mathrm{cm}$ to $\mathrm{km}$ ), a sessile organism may survive by growing on a substratum where sources of mortality are absent or significantly reduced (e.g. Grosberg 1981, Young \& Chia 1981, 1984). On a smaller scale ( $\mu \mathrm{m}$ to $\mathrm{cm}$ ), specific locations within topographically complex surtaces may enhance survival (e.g. Connell 1961, Keough \& Downes 1982, Lubchenco 1983, LeTourneux. \& Bourget 1988, Walters 1992a).

On topographically complex hard substrata, pits and crevices are predicted to provide refuge for sessile invertebrates from predators and physical disturbances (Barry \& Dayton 1991), while topographic high spots may provide refuge for poor spatial competitors (Connell \& Keough 1985). However, these predictions are not always supported in the literature. For example, in a subtidal habitat where fish predation is intense, Keough \& Downes (1982) found higher survival for 2 of 4 sessile invertebrates in pits (diameter: $5 \mathrm{~cm}$; depth: $5 \mathrm{~cm}$ ) relative to flat surfaces. However, when recruits of the arborescent bryozoan Scrupocellaria brunnea grew above the rims of the pits, survival was no longer greater in this location. Additionally, Walters (1992a) found that the effectiveness of bases of $2 \mathrm{~mm}$ roughness elements (crevices) for the arborescent bryozoan Bugula neritina was dependent on the size of the predators in the system. With new recruits of the barnacle Semibalanus balanoides, Connell (1961) found greater survival after a storm on concave surfaces than convex surfaces (scale: $\mathrm{mm}$ to $\mathrm{cm}$ ). Likewise, Chabot \& Bourget (1988) found that ice scour killed $>95 \%$ of the juvenile barnacles not in crevices (mean crevice depth: $8.5 \mathrm{~cm}$ ). In contrast, Wethey (1984) found no increase in survival of the barnacle $S$. balanoides during the first week after settlement in 0.5 to $1.0 \mathrm{~mm}$ cracks on rock surfaces subject to intense water motion. Additionally, survival of barnacles in crevices on the cordgrass Spartina alterniflora $145^{\circ}$ angle where leaf and stem intersect) was significantly lower than on leaves or stems for the first $24 \mathrm{~h}$ post-settlement and throughout the next $9 \mathrm{~d}$ (Young 1991). On topographic highs, Walters \& Wethey (1986) showed that a $1.6 \mathrm{~mm}$ height advantage in the zone of contact reversed the predicted overgrowth interaction for competitive interactions between some encrusting invertebrates (Alcyonidium hirsutum vs Electra pilosa), but not others (A. hirsutum vs Botryllus schlosseri).

These conflicting results show that refuge quality depends on the relative dimensions of the refuge and the organism and the susceptibility of the individual to mortality at any given point in time. At the time of settlement, the dimensions of larval forms are frequently small (scale: $\mu \mathrm{m}$ to $\mathrm{cm}$ ) relative to the dimensions of many possible refuges, and survival during this vulnerable phase is predicted to be enhanced in these locations. With growth, the relative dimensions change as a function of the individual's growih form. Organisms with limited attachment to the substrata (e.g. solitary and clonal arborescent forms) are predicted to be very susceptible to outright mortality, and thus should rely heavily on selecting high quality refuges and remaining in the confines of these refuges throughout their lifetimes or until size refuges are obtained (Jackson 1977, 1979, Keough 1986). Organisms with unlimited attachment to the substrata (e.g. clonal stolon-mat forms with runners from which upright axes develop and clonal encrusting forms) are predicted to rarely be completely killed; partial mortality should occur more commonly in organisms with these growth forms (Jackson \& Hughes 1985). Thus, these larvae may be somewhat less selective at the time of settlement. Immediately following metamorphosis or at some later time, survival will not be increased in refuges, and these individuals should expand laterally beyond the dimensions of the refuge (Jackson 1977, Jackson \& Hughes 1985).

On topographically complex surfaces, the distribution of settled larvae is rarely random (e.g. Dean 1981, LeTourneux \& Bourget 1988, Walters \& Wethey 1991). To date, many studies have shown that hydrodynamics alone (e.g. Wethey 1986, Butman 1987, Havenhand \& Svane 1991, Harvey et al. 1995) or in combination with larval behavior (e.g. Crisp 1981, Pawlik et al. 1991, Walters 1992b, Mullineaux \& Garland 1993) determine where an individual settles. Either alternative can result in preferential settlement in pits and crevices (e.g. Crisp \& Barnes 1954, LeTourneux \& Bourget 1988, Raimondi 1990, WaIters \& Wethey 1991, Walters $1992 b$ ), while some amount of larval behavior is predicted to be involved when larvae settle on topographic highs (Walters \& Wethey 1991).

As part of a larger study on how natural topographic complexity influences the success of marine organisms 
(Walters 1991), we were interested in understanding the mechanisms underlying the distribution of sessile invertebrates with different growth forms attached to the solitary ascidian Styela plicata (hereafter Styela). This animal is covered with roughness elements of various sizes that can potentially alter the settlement and survivorship of epibionts. In North Carolina (USA) waters, Styela is frequently $100 \%$ covered by 4 sessile invertebrates with unique growth morphologies: a solitary form, the barnacle Balanus sp. $(95 \%$ B. amphitrite, $5 \%$ B. eberneus and B. improvisus; D. Rittschof pers. comm.); a clonal arborescent form, the bryozoan $B u-$ gula neritina (hereafter Bugula); a clonal encrusting form, the bryozoan Schizoporella errata (hereafter Schizoporella); and a clonal stolon-mat form, the hydrozoan Tubularia crocea (hereafter Tubularia). Our analysis was carried out in 2 phases: (1) we examined settlement on topographically complex surfaces of Styela and on artificial substrata with uniformly spaced roughness elements or pits that mimicked the types and scale of topographic complexity found on Styela, and (2) we examined daily survival in all possible settlement locations. From this data, we were able to determine if larvae settled preferentially in refuges and what size refuges were preferred. Additionally, we compared larval dimensions to refuge dimensions to see if larvae could have potentially been excluded from any locations and we measured the height and lateral expansion of individuals with different growth forms $7 \mathrm{~d}$ after settlement to see if individuals with different growth forms remained within the boundaries of the refuges.

\section{MATERIALS AND METHODS}

On the floating dock at the Duke University Marine Laboratory in Beaufort, North Carolina (34 $43^{\prime} 03^{\prime \prime} \mathrm{N}$, $76^{\circ} 40^{\prime} 18^{\prime \prime} \mathrm{W}$ ), the solitary ascidian Styela plicata is the primary substratum for recruitment of sessile invertebrates during summer (Sutherland \& Karlson 1977, Sutherland 1978). Styela individuals used in these trials measured $44.7 \pm 0.7 \mathrm{~mm}$ (mean $\pm \mathrm{SE}$ ) in length and $23.2 \pm 0.2 \mathrm{~mm}$ in width when measured without disturbance under water. The roughness elements on their surfaces were composed of a solid cellulose matrix and ranged from 0.6 to $8.8 \mathrm{~mm}$ in height (mean: $3.1 \pm 0.1 \mathrm{~mm}$ ). Approximately $2 / 3$ of each individual was covered by roughness elements (bumps and ridges).

Settlement on topographically complex surfaces of Styela plicata. The locations of all newly settled sessile invertebrate larvae were recorded relative to roughness elements on 81 experimentally denuded Styela between June 2 and 11, 1993. Styela were collected from the floating dock and all attached flora and fauna were removed with watchmaker's forceps and a softbristled toothbrush. After $48 \mathrm{~h}$ in running seawater tables, healthy, clean Styela were randomly attached to one of nine $20 \times 20 \mathrm{~cm}$ plastic mesh squares (Vexar: $5 \times 8 \mathrm{~mm}$ openings) with plastic cable ties ( $6 \mathrm{~cm}$ apart). To eliminate flow through the mesh, each square was attached to a $1 \mathrm{~mm}$ thick plexiglass plate of the same dimensions. Plates were randomly attached to one of 3 PVC pipes (diameter: $2.5 \mathrm{~cm}$ ) with countersunk stainless steel screws. Plates were hung face-down underneath the dock $(25 \mathrm{~cm}$ apart) to mimic the normal growth orientation of Styela in this habitat and eliminate siltation. Pipes were hung parallel to each other (70 $\mathrm{cm}$ apart) and parallel to the direction of the current

After $48 \mathrm{~h}$ of submersion, the locations of all newly settled individuals were measured relative to the roughness elements on each Styela with vernier calipers. First, we determined if each larva settled in contact with a roughness element or on the surface between roughness elements. If the individual settled in contact with a roughness element, the height of the roughness element $\left(\mathrm{H}_{\mathrm{re}}\right.$ ) and the height of the settled larva above the base of roughness element $\left(\mathrm{H}_{1}\right)$ were recorded in mm. A scaled vertical position $\left(\mathrm{H}_{1} / \mathrm{H}_{\text {r.e. }}\right)$ was then calculated for each individual to determine how close to the base of the roughness element it attached. To determine if different size roughness elements were preferred, we calculated the proportion of larvae that settled on small $(\leq 2.0 \mathrm{~mm})$, medium $(2.0<x$ $\leq 5.0 \mathrm{~mm}$ ) or large (>5.0 mm) roughness elements. All statistical calculations were run in SAS 6.03 (SAS Institute 1988): the categorical modeling procedure (CATMOD) with a posteriori Bonferroni comparisons was used to analyze the count data (on/off roughness elements, proportion on each size roughness elements); 1 -way analysis of variance (ANOVA) with a posteriori Bonferroni comparisons was used to compare the mean scaled vertical position of each species on the roughness elements.

Settlement and survival on artificial substrata. It was not possible to run longer trials with Styela as the substratum because Styela individuals did not survive continued removal from the water for microscopic examination. To model the topographies found on Styela, round settlement plates, $8.9 \mathrm{~cm}$ in diameter and $6.0 \mathrm{~mm}$ thick, of 2 topographies were deployed: (1) $5.0 \mathrm{~mm}$ high, equidistant, cylindrical roughness elements, and (2) $2.0 \mathrm{~mm}$ high, equidistant, cylindrical roughness elements (Fig. 1), We additionally considered settlement in hemispherical pits. These surfaces are superificialiy siñilar to the arcas botween roughness elements, but lack the sharp angle where the roughness element and flat surface intersect (Fig. 1). 


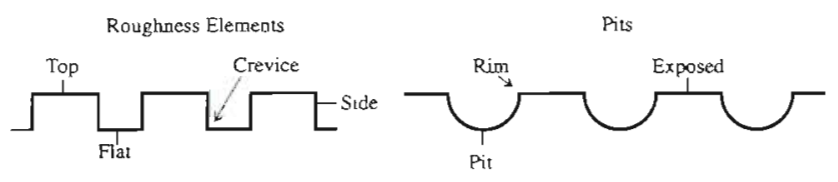

\begin{tabular}{lccc} 
Plate type & Height or depth & Diameter & Spacing \\
\hline $5.0 \mathrm{~mm}$ r.e. & 5.0 & 9.0 & 6.0 \\
$2.0 \mathrm{~mm}$ r.e. & 2.0 & 5.0 & 3.0 \\
$5.0 \mathrm{~mm}$ pit & 5.0 & 9.0 & 10.0 \\
$2.0 \mathrm{~mm}$ pit & 2.0 & 5.0 & 4.0
\end{tabular}

Fig. 1 Dimensions (in $\mathrm{mm}$ ) and locations of topographic features on settlement plates. Arrows on diagrams point to specific locations on surfaces (crevice, rim); lines point to larger topographic features (e.g. top of roughness element, pit). Height or depth: maximum height on plates with roughness elements (r.e.) or maximum depth on plates with pits; Diameter: diameter of r.e. or pits; Spacing: minimum distance to adjacent r.e. or pits

We considered (3) $5.0 \mathrm{~mm}$ deep, equidistant, hemispherical pits, and (4) $2.0 \mathrm{~mm}$ deep, equidistant, hemispherical pits (Fig. 1). Commercially available materials with topographies that correspond to the numbers above are: (1) small Lego building blocks (Lego Systems Inc.), (2) large Lego (Duplo) building blocks, (3) rolls of bubble plastic, and (4) plastic Chinese checker boards. Multiple, identical settlement plates were produced by pouring polyester resin into silicone rubber molds (Sylgard 184 Silicone Elastomer, Dow Corning Corp.) created from each topography. Black resin pigment (Titan Corp.) was added to the uncatalyzed resin to make newly settled larvae more visible on the plates.

Before running the first trial, plates were soaked in running seawater for 4 wk and then cleaned with a softbristled toothbrush. Nine $7 \mathrm{~d}$ trials were run in 1989 and 1990 (starting dates - 1989: August 20, September 15 , October 1; 1990: May 19, June 16, July 17. August 19, September 16, and October 10). One settlement plate of each topography was attached to a PVC pipe with countersunk stainless steel screws and suspended facedown directly beneath the floating dock as described above. Plates were arranged in a Latin square design. Observations were made daily to determine where larvae had attached over the previous $24 \mathrm{~h}$. From maps made of the locations of all settlers, we were also able to determine if any previously settled larvae had died and how old each individual was when it died. To make these observations, plates were removed from the dock, brought into the laboratory in seawater-filled buckets and immediately put into a running seawater table. Plates were observed individually with a dissecting microscope while submerged. It took less than 5 min to examine each plate. Each plate remained in the laboratory for less than 30 min each day.
The plates with roughness elements were divided into 4 potential settlement locations: (1) tops, (2) sides (3) bases of roughness elements, i.e. crevices, and (4) flat areas $>0.25 \mathrm{~mm}$ from the roughness elements. On the plates with pitted surfaces, 3 locations were considered: (1) in pits, (2) rims of pits extending out to $0.25 \mathrm{~mm}$, and (3) the remaining exposed area between pits. The areas occupied by each of these locations on all topographies are presented in Table 1. To ensure that all observations were independent, only 1 type of location was observed on each plate. The location observed on each plate was chosen randomly, but remained constant throughout a trial. Three replicates of each plate type/location combination were observed during each $7 \mathrm{~d}$ trial.

Larval settlement varied tremendously over time. Weekly cumulative totals ranged from a high of 8669 settlers (September 15, 1989) to a low of 684 settlers (July 17, 1991). To detemine if settiement of each species with at least 12 settlers per trial differed from random on the 4 plate types, the mean density of settlers $\left(\mathrm{N} \mathrm{cm}^{-2}\right)$ was calculated for each location for each trial. The repeatability of the settlement results between trials, especially when there are large differences in cumulative settlement, is critical in making generalizations about settlement location preferences. To determine the repeatability of results between trials, we used a 1-way ANOVA, considering the trials as replicates, and the mean settlement densities in each trial as our observations. Then we used an a priori contrast, comparing the settlement density in pits or crevices to the mean settlement density in all other sites.

Table 1. Surface area $\left(\mathrm{mm}^{2}\right)$ and percent of the total area covered by each topographic feature on each type of settlement plate. As all plates were cast from the same original material, the surface areas occupied by each topographic feature did not differ among replicates. r.e.: roughness elements

\begin{tabular}{|clrc|}
\hline Plate type & Location & Surface area & \% total area \\
\hline 5.0 mm r.e. & Top & 1134.1 & 17.8 \\
& Side & 2387.6 & 37.6 \\
& Crevice & 122.6 & 1.9 \\
& Flat & 2712.5 & 42.7 \\
$2.0 \mathrm{~mm}$ r.e. & Top & 1806.9 & 22.1 \\
& Side & 3179.3 & 38.8 \\
& Crevice & 379.0 & 4.6 \\
& Flat & 2821.6 & 34.5 \\
$5.0 \mathrm{~mm}$ pit & Pit & 2240.6 & 30.0 \\
& Rim & 125.6 & 1.7 \\
& Exposed & 5115.8 & 68.3 \\
$2.0 \mathrm{~mm}$ pit & Pit & 3838.8 & 46.4 \\
& Rim & 379.3 & 4.6 \\
& Exposed & 4063.2 & 49.0 \\
\hline
\end{tabular}


To measure short-term survival ( $\leq 7 \mathrm{~d}$ ), we followed all individuals that settled during the $7 \mathrm{~d}$ trials, and determined the proportion of settlers that died each day and the number of days from settlement to death. We regressed the log of the proportion surviving against time. The slope of this regression is the mortality rate (per day). All regression lines were forced through 0 ( $\log$ of 1 ) because the proportion alive was 1 at time zero. We used analysis of covariance to compare the slopes of the lines among locations on each plate type. When the analysis of covariance showed an overall difference in the slopes among locations, we used Bonferroni t-tests (Miller 1966) to make simultaneous comparisons among the slopes to determine which locations differed from each other.

Dimensions of larvae and $\mathbf{7} \mathbf{d}$ individuals. To determine if larval dimensions exceeded the dimensions of potential refuges on Styela or plates with complex topographies, we measured the overall dimensions of competent larvae of each species $(\mathrm{N}=30)$ with an ocular micrometer attached to a dissecting microscope.

To determine the dimensions of $7 \mathrm{~d}$ recruits that settled in potential refuge locations, Bugula and Schizoporella were allowed to attach to all plate surfaces in the laboratory using the methods described in Walters (1992a). Simultaneously, plates were suspended off the floating dock to collect Tubularia and Balanus recruits. After $24 \mathrm{~h}$, all but individuals in crevices or pits were removed and the locations of all survivors mapped. Then, all plates were suspended from the dock as described above for $6 \mathrm{~d}$ beginning on June 1, 1993. For normal growth to occur in this habitat, neither spatial competitors nor predators were excluded during this period. It is unlikely that partial mortality biased growth measures because all sources of mortality kill whole individuals when they are within this size range (Keough 1986, Walters 1992a). At the end of the trial, plates were removed from the water and the height and lateral expansion of thirty $7 \mathrm{~d}$ individuals of each species in each refuge location were measured with either an ocular micrometer attached to a dissecting microscope or vernier calipers.

\section{RESULTS}

\section{Settlement on Styela}

A total of 412 larvae settled on 81 clean Styela individuals within $48 \mathrm{~h}$. Among these individuals, there were significant overall differences in settlement location relative to the roughness elements $\left(\chi^{2}=15.95 ; \mathrm{df}=\right.$ 3, 412i $p=0.0012$ ) (Table 2). A significantly higher percentage of Balanus individuals ( $94 \%$ ) settled in contact with the roughness elements than Tubularia (76\%) or Schizoporella (67\%). Additionally, Bugula $(81 \%)$ settled in contact with roughness elements significantly more than Schizoporella (Table 2). Of the 327 larvae that settled in contact with the roughness elements, over $72 \%$ of each species settled in contact with roughness elements $>2.0$ and $\leq 5.0 \mathrm{~mm}$ (Table 2 ). Additionally, Balanus and Bugula attached significantly closer to the bases of the roughness elements than Tubularia and Schizoporella $(F=30.39$; $\mathrm{df}=3,327 ; \mathrm{p}=$ 0.0001 ) (Table 2).

\section{Settlement and survival on artificial surfaces with uniform topographies}

All species settled non-randomly on plates with uniformly spaced roughness elements (Table 3). Settlement of Balanus, Bugula, Schizoporella and Tubularia was greatest in the $90^{\circ}$ angle formed at the bases of the roughness elements (crevices). These results were consistent regardless of the number of settlers in a trial and the height of the roughness elements (F-tests; Table 3).

Settlement preference results were less consistent on the pitted surfaces ( $F$-tests; Table 3 ). Balanus settled

Table 2. Larval settlement locations on Styela plicata. Touching r.e.: mean proportion of individuals that settled in contact with roughness elements (r.e.) on the surface of Styela. The remaining values are calculated only for individuals that settled in contact with r.e. Vertical position (scaled): mean (height of the individual above the base of r.e. in $\mathrm{mm}$ )/(the height of the r.e. in mm); On r.e. $\leq 2.0 \mathrm{~mm}$ high: mean proportion of individuals that settled on r.e. in this size range; On r.e. $2.0<x \leq 5.0 \mathrm{~mm}$ high: mean proportion of individuals that settled on r.e. in this size range. If vertical bars following the means overlap, then the results of a posteriori Bonferroni comparisons were not significantly different at the $p<0.05$ level. (SE in parentheses)

\begin{tabular}{|c|c|c|c|c|c|}
\hline Species & $N$ & $\begin{array}{l}\text { Touching } \\
\text { r.e. }\end{array}$ & $\begin{array}{l}\text { Vertical } \\
\text { position }\end{array}$ & $\begin{array}{c}\text { On r.e. } \\
\leq 2.0 \mathrm{~mm} \text { high }\end{array}$ & $\begin{array}{c}\text { On r.e. } \\
2.0<x \leq 5.0 \mathrm{~mm} \text { high }\end{array}$ \\
\hline Balanus sp. & 72 & $94.44(2.72)$ & $0.10(0.02)$ & $19.18(4.80)$ & $72.06(5.48)$ \\
\hline Rurgula neritina & 148 & $81.08(3.23)$ & $0.15(0.02) \mid$ & $20.00(3.66)$ & $77.50(3.82)$ \\
\hline Tubularia crocea & 107 & $76.64(4.11)$ & $0.48(0.04) \mid$ & $10.98(3.4 t))$ & $04.15(4.00)$ \\
\hline Schizoporella errata & 85 & $67.06(5.13)$ & $0.41(0.04)$ & $14.04(4.64)$ & $82.46(5.08) !$ \\
\hline
\end{tabular}


Table 3. Mean settlement preferences for each species on each plate type. Trials: number of trials used in the analyses ( $N \geq 12$ individuals); $N$ : mean number of settlers; Number of settlers $\mathrm{cm}^{-2}$. mean number of settlers $\mathrm{cm}^{-2}$ in each location on setllement plates; p: probability the a priori hypothesis that the settlement density in potential refuges (crevices, pits) wus equal to the mean settlement density in other locations; r.e.: roughness elements; na: not applicable as no larvae settled on this surface. (SE in parentheses)

\begin{tabular}{|c|c|c|c|c|c|c|c|c|c|c|}
\hline \multirow[t]{2}{*}{ Species } & \multirow[t]{2}{*}{ Plate } & \multirow[t]{2}{*}{ Trials } & \multirow[t]{2}{*}{$N$} & \multicolumn{4}{|c|}{ Number of settlers $\mathrm{cm}^{-2}$} & \multirow[t]{2}{*}{$F$} & \multirow[t]{2}{*}{$d f$} & \multirow{2}{*}{$p$} \\
\hline & & & & Top & Side & Crevice & Flat & & & \\
\hline Balanus & 5.0 r.e. & 9 & $645.22(215.02)$ & $1.46(0.50)$ & $0.96(0.40)$ & $44.72(15.50)$ & $4.4 .1(1.47)$ & 22.17 & 1,32 & 0.0001 \\
\hline Bugula & 5.0 re. & 5 & $20.00(4.02)$ & $0.08(0.04)$ & $0.05(0.02)$ & $2.01(0.43)$ & $0.08(0.01)$ & 61.63 & 1,16 & 0.0001 \\
\hline Schizoporella & 5.0 ree. & 4 & $18.25(4.63)$ & $0.13(0.04)$ & $0.02(0.01)$ & $0.82(0.34)$ & $0.15(0.04)$ & 12.73 & 1,12 & 0.0029 \\
\hline Tubularia & 5.0 ree. & 2 & $19.50(6.50)$ & $0.19(0.16)$ & $0.09(0.01)$ & $0.95(0.41)$ & $0.04(0.04)$ & 10.98 & 1,4 & 0.0295 \\
\hline Balanus & 2.0 ree. & 9 & $665.33(218.65)$ & $0.31(0.11)$ & $0.07(0.03)$ & $20.53(9.42)$ & $3.26(1.03)$ & 12.47 & 1,32 & 0.0013 \\
\hline Bugula & 2.0 r.e. & 5 & $38.40(17.23)$ & $0.07(0.04)$ & $0.01(0.01)$ & $181(0.75)$ & $0.10(0.05)$ & 16.30 & 1,16 & 0.0010 \\
\hline Schizoporella & 2.0 r.e. & 7 & $21.57(4.63)$ & $0.07(0.03)$ & $0.00(0.00)$ & $0.71(0.18)$ & $0.07(0.02)$ & 40.08 & 1,24 & 0.0001 \\
\hline \multirow[t]{2}{*}{ Tubularia } & 2.0 ree & 3 & $19.33(3.84)$ & $0.07(0.04)$ & $0.03(0.00)$ & $1.00(0.03)$ & $0.01(0.00)$ & 34.53 & 1,8 & 0.0004 \\
\hline & & & & Pit & & Rim & Exposed & & & \\
\hline Balanus & 5.0 pit & 9 & $592.67(200.15)$ & $5.88(1.70)$ & 0.94 & $(0.27)$ & $1.26(0.62)$ & 13.68 & 1,24 & 0.0011 \\
\hline Bugula & 5.0 pit & 5 & $32.00(15.01)$ & $0.20(0.09)$ & 0.11 & $(0.11)$ & $0.12(0.06)$ & 24.30 & 1,9 & 0.0008 \\
\hline Schizoporella & 5.0 pit & 5 & $20.00(3.38)$ & $0.19(0.06)$ & 0.38 & $(0.25\}$ & $0.04(0.00)$ & 0.01 & 1.12 & 0.9217 \\
\hline Tubularia & 5.0 pit & 0 & & & & & & & & na \\
\hline Balanus & 2.0 pit & 9 & $572.44(183.21)$ & $4.25(1.22)$ & 0.47 & $(0.15)$ & $0.64(0.39)$ & 16.38 & 1,24 & 0.0005 \\
\hline Bugula & 2.0 pit & 3 & $36.00(11.53)$ & $0.13(0.02)$ & 0.32 & $(0.28)$ & $0.14(0.06)$ & 0.24 & 1,6 & 0.6439 \\
\hline Schizoporella & 2.0 pit & 8 & $25.25(3.18)$ & $0.18(0.03)$ & 0.01 & $(0.01)$ & $0.04(0.00)$ & 51.55 & 1,21 & 0.0001 \\
\hline Tubuldild & $2.0 \mathrm{put}$ & 0 & & & & & & & & na \\
\hline
\end{tabular}

preferentially in both $5.0 \mathrm{~mm}$ and $2.0 \mathrm{~mm}$ deep pits (Table 3). Bugula settled preferentially in large pits but not in small ones (Table 3). The clonal encrusting form, Schizoporella, settled randomly on surfaces with $5.0 \mathrm{~mm}$ pits, and preferentially in $2.0 \mathrm{~mm}$ pits (Table 3 ). No Tubularia settled on the plates with pits.

Regressions of mortality versus time in each location on each plate type are combined for all trials in Table 4 . The rate of Balanus mortality ( $\left.\% \mathrm{~d}^{-1}\right)$ was significantly lower in crevices on plates with both size roughness elements (the preferred settlement location; Table 3) than on the tops or the flat areas between roughness elements (Table 4 ). On the pitted surfaces, Balanus mortality was significantly lower in pits where larval settlement was densest (Tables 3 \& 4). Bugula mortality was also significantly lower in crevices than all other locations on plates with $2.0 \mathrm{~mm}$ roughness elements, while daily mortality rates in crevices on plates with $5.0 \mathrm{~mm}$ roughness elements was less than half the mortality on the tops of these roughness elements ( 6.6 vs $14.0 \% \mathrm{~d}^{-1}$ ). Bugula mortality was highest on the rims of the large pits and in the bottoms of the small pits (Table 4). For Schizoporella recruits, mortality on plates with $5.0 \mathrm{~mm}$ roughness elements only occurred in the locations where large flat surfaces were exposed. On the tops of the roughness elements, mortality was $8 \% \mathrm{~d}^{-1}$ while on the flat areas between bumps, mortality approached $24 \% \mathrm{~d}^{-1}$. No Schizoporella recruits died during any trial on the sides or in crevices on the large roughness elements (Table 4). Therefore, again, the preferred settlement location (crevices) significantly reduced rates of mortality. Mortality of Schizoporella was very low in all locations on plates with $2.0 \mathrm{~mm}$ roughness elements. On the surfaces with $5.0 \mathrm{~mm}$ deep pits, Schizoporella mortality did not differ between locations, while on the surfaces with $2.0 \mathrm{~mm}$ deep pits, Schizoporella mortality was greatest in the pits (Table 4), the locations with the highest settlement (Table 3). Tubularia survival did not differ among locations on either surface with roughness elements (Table 4).

\section{Dimensions of competent larvae and $7 \mathrm{~d}$ recruits in relation to refuges}

The dimensions of potential refuges considered in these trials greatly exceeded the dimensions of larvae of Balanus, Bugula and Schizoporella (Table 5). When fully expanded, Iarvae of Tubularia exceeded $1.2 \mathrm{~mm}$ in diameter (Table 5). On Styela, the smallest roughness elements where any larval settlement occurred were $0.6 \mathrm{~mm}$ high. Thus, Tubularia larvae may have been excluded from certain spots.

The height of $7 \mathrm{~d}$ Balanus individuals was never greater than the height of the roughness elements or the depth of the pits (Table 6). Thus, all individuals that settled in crevices on plates with roughness elements 
Table 4. Short-term ( $\leq 7 \mathrm{~d})$ mortality rates (\% dead $\mathrm{d}^{-1}$ ) for each location on each plate type. p: probability values based on analysis of covariance tests (ANCOVA) used to compare the slopes of lines for each location. When ANCOVA showed overall differences among locations, Bonferroni $t$-tests were used to make simultaneous comparisons among slopes. Rank: order of differences based on the Bonferroni comparisons; r.e.: roughness elements; na: not applicable as no larvae settled on this surface

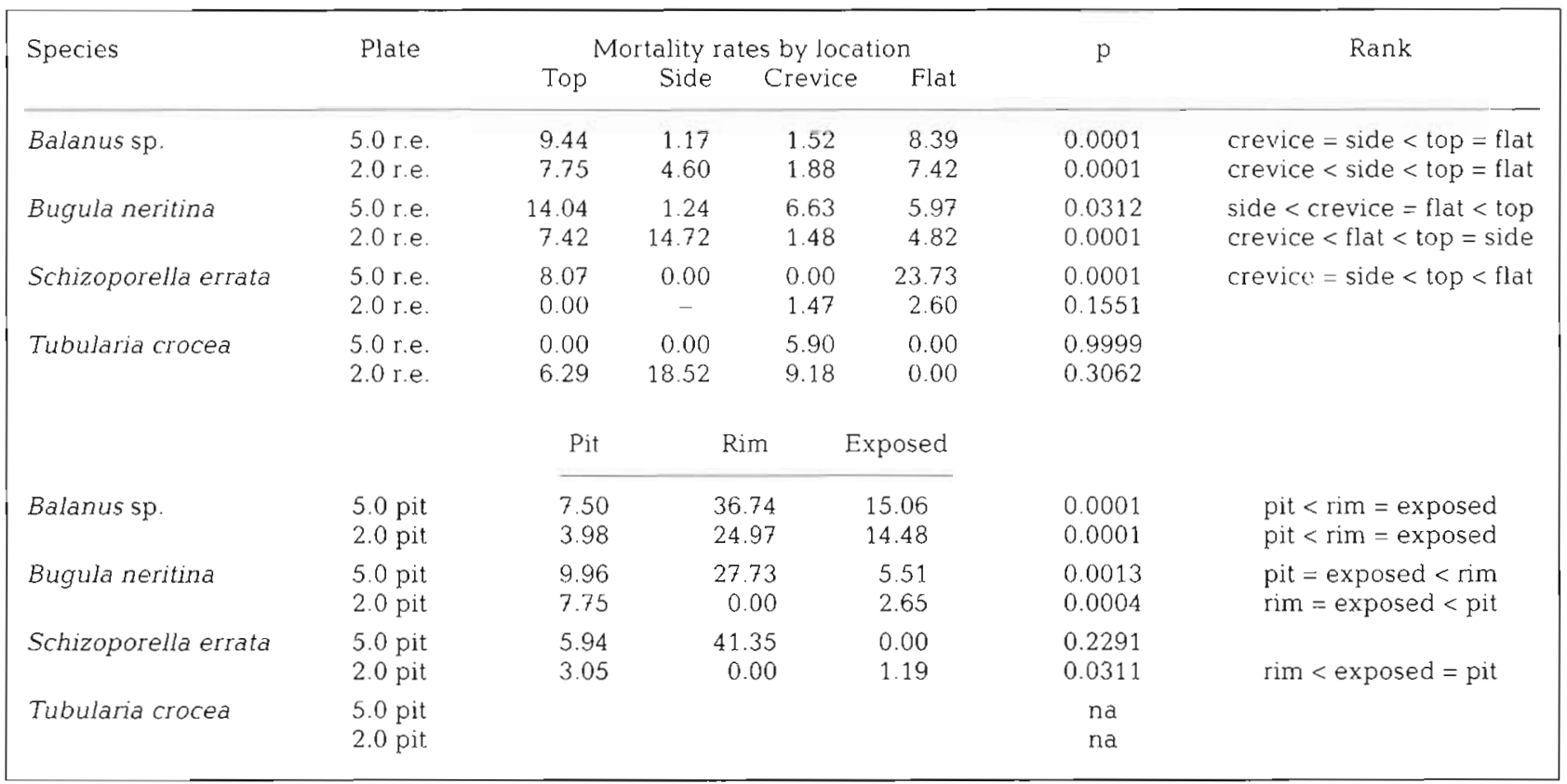

would remain within the boundaries of the refuge throughout the week, while the success of Balanus recruits in pits was in part determined by settlement location within the pits. Those settling near the bases of the pits should remain protected within the refuge; those settling near the rim may rapidly exceed the boundaries of the refuge. Lateral expansion in Bugula was limited to the width of the attachment zooid, while upward growth exceeded $2.8 \mathrm{~mm}$ in all tested locations (Table 6). Thus, all Bugula recruits that settled in crevices on $2.0 \mathrm{~mm}$ roughness elements or anywhere in $2.0 \mathrm{~mm}$ pits were exposed to predators and disturbance events within $7 \mathrm{~d}$. However, individuals in crevices on $5.0 \mathrm{~mm}$ roughness elements should remain protected, while exposure of Bugula recruits in $5.0 \mathrm{~mm}$ pits was dependent on the exact settlement location. Upward growth of the new recruits of Schizoporella was limited to the thickness of the zooids; most of the growth of this encrusting form was lateral (Table 6). Within $7 \mathrm{~d}$, recruits on plates with roughness elements covered an area at least $1.7 \mathrm{~mm}$ in diameter. Thus, most of the colony would be no longer near the crevice and either growing up the side of the roughness element or into the flat area between bumps. On pitted surfaces, Schizoporella also covered an area at least $1.7 \mathrm{~mm}$ in diameter. As with Balanus and Bugula, exposure of recruits of Schizoporella in pits was dependent on the settlement location. Tubularia grew rapidly on surfaces with roughness elements (Table 6). If daily growth is approximately $1 / 7$ of total growth,

Table 5. Larval and adult morphologies of sessile invertebrates that settled on Styela plicata and on the settlement plates and the mean dimensions of these larvae in $\mu \mathrm{m}$ ( $\mathrm{SE}$ in parentheses) $(\mathrm{N}=30$ )

\begin{tabular}{|c|c|c|c|}
\hline Species & Larval morphology & Larval dimensions & Adult morphology \\
\hline Balanus sp. & Cyprid & $\begin{array}{l}\text { Length: } 356.7(9.30) \\
\text { Width: } 159.38(3.21)\end{array}$ & Aclonal, solitary \\
\hline Bugula neritina & Coronate & Diameter: $166.67(3.12)$ & Clonal, arborescent \\
\hline Schizoporclia crata & Coronate & Diameter: 207.69 (6.28) & Clonal, encrusting \\
\hline Tubularia crocea & Actinula & $\begin{array}{l}\text { Diameter of central disc: } 260.00(5.34) \\
\text { Diameter with arms extended: } 1269.33(29.83)\end{array}$ & Clonal, stolon-mat \\
\hline
\end{tabular}


Table 6. Dimensions of $7 \mathrm{~d}$ individuals in potential refuge locations Mean height and lateral expansion in mm on Day 7 (SE in parentheses) for individuals ( $N=30$ ) that settled in crevices and pits on settlement plates; r.e.: roughness elements; na: not applicable

\begin{tabular}{|c|c|c|c|c|}
\hline Species & Plate & Location & Height & Lateral expansion \\
\hline Balanus sp. & $\begin{array}{l}5.0 \text { r.e. } \\
2.0 \text { ree. } \\
5.0 \text { pit } \\
2.0 \text { pit }\end{array}$ & $\begin{array}{l}\text { Crevice } \\
\text { Crevice } \\
\text { Pit } \\
\text { Pit }\end{array}$ & $\begin{array}{l}1.13(0.04) \\
0.97(0.05) \\
1.02(0.04) \\
1.01(0.04)\end{array}$ & $\begin{array}{l}1.34(0.04) \\
1.18(0.04) \\
1.40(0.03) \\
1.31(0.03)\end{array}$ \\
\hline $\begin{array}{l}\text { Bugula } \\
\text { neritina }\end{array}$ & $\begin{array}{l}5.0 \text { r.e. } \\
2.0 \text { r.e. } \\
5.0 \text { pit } \\
2.0 \text { pit }\end{array}$ & $\begin{array}{l}\text { Crevice } \\
\text { Crevice } \\
\text { Pit } \\
\text { Pit }\end{array}$ & $\begin{array}{l}3.12(0.05) \\
2.99(0.04) \\
2.80(0.06) \\
2.85(0.06)\end{array}$ & $\begin{array}{l}0.36(0.01) \\
0.38(0.02) \\
0.40(0.01) \\
0.41(0.02)\end{array}$ \\
\hline $\begin{array}{l}\text { Schizoporella } \\
\text { errata }\end{array}$ & $\begin{array}{l}5.0 \text { r.e. } \\
2.0 \text { r.e. } \\
5.0 \text { pit } \\
2.0 \text { pit }\end{array}$ & $\begin{array}{l}\text { Crevice } \\
\text { Crevice } \\
\text { Pit } \\
\text { Pit }\end{array}$ & $\begin{array}{l}0.28(0.01) \\
0.23(0.01) \\
0.29(0.01) \\
0.28(0.02)\end{array}$ & $\begin{array}{l}2.00(0.06) \\
1.74(0.10) \\
1.91(0.06) \\
1.68(0.07)\end{array}$ \\
\hline $\begin{array}{l}\text { Tubularia } \\
\text { crocea }\end{array}$ & $\begin{array}{l}5.0 \text { r.e. } \\
2.0 \text { r.e. } \\
5.0 \text { pil } \\
2.0 \text { pit }\end{array}$ & $\begin{array}{l}\text { Crevice } \\
\text { Crevice } \\
\text { Pit } \\
\text { Pit }\end{array}$ & $\begin{array}{c}13.68(0.46) \\
1181(0.40) \\
\text { na } \\
\text { na }\end{array}$ & $\begin{array}{c}9.69(0.37) \\
10.24(0.32) \\
\text { na } \\
\text { na }\end{array}$ \\
\hline
\end{tabular}

enhanced (Table 4). Settlement locations and locations where survival was enhanced were less consistent for the 2 species with unlimited attachment to the substrata. Both Schizoporella (clonal, encrusting) and Tubularia (clonal, stolon-mat) did not always settle on the roughness elements on Styela and when they did, they settled all along the roughness elements rather than at the bases (Table 2). Both species did, however, settle in significantly greater numbers at the bases of the roughness elements on plates (Table 3). Shortterm survival of Schizoporella was increased in crevices on $2.0 \mathrm{~mm}$ roughness elements, but not the $5.0 \mathrm{~mm}$ bumps (Table 4). Survival of Tubularia was not increased in either of the tested crevice locations (Table 4).

Roughness elements and pits can be considered eñds of a cunitinuum, since ail nonplanar surfaces have a highest point and a lowest point. However, pits were frequently poorer quality refuges than crevices (Table 4). Although both are considered depositional re-

then Tubularia on plates with both size roughness elements were out of the boundaries of the $2.0 \mathrm{~mm}$ crevice refuges in $2 \mathrm{~d}$ and $5.0 \mathrm{~mm}$ crevices in $3 \mathrm{~d}$.

\section{DISCUSSION}

We predicted that individuals with unlimited attachment to the substrata would rapidly be protected by their growth form, decreasing their need to settle in refuges and limiting the length of time any locations on heterogeneous substrata act as refuges. We also predicted that organisms with limited attachment to the substrata would remain susceptible to mortality for a longer time and as a result should be much more consistent about settling in high quality refuges. The results agreed with the predictions for the 4 species tested on both the topographically complex surface of the ascidian Styela plicata and on settlement plates with uniformly spaced roughness elements. Both species with limited attachment to the substrata settled very specifically in locations that acted as refuges throughout the first week post-settlement (Tables 2 to 4). The aclonal, solitary form (Balanus) settled almost exclusively near the bases of roughness elements on Styela and in crevices on plates with large and small roughness elements. Most Balanus recruits remained within the boundaries of these refuges throughout the following week and survival was increased in these locations. The clonal, arborescent form (Bugula) also consistently settled in crevices on Styela and on roughness element plates (Tables 2 \& 3) where survival was gions (e.g. Middleton \& Southward 1984), the settlement and survival results for individuals in crevices vs pits of the same magnitude were often different (Tables $3 \& 4)$. This may be because larvae can not securely attach to the pitted surfaces which lack sharp angles, such as those created where flat surfaces and roughness elements intersect (Fig. 1; LeTourneux \& Bourget 1988). Additionally, these results may differ because we combined all settlement in pits, although some individuals settled near the bases of the pits and others settled near the rims, or because the diameter of the pits was greater than the spacing between roughness elements (Fig. 1). No Tubularia ever settled on surfaces with pits (Table 3). It is not known if these larvae were: (1) excluded from at least the small pits due to their large dimensions (Table 5), (2) actively rejecting these surfaces, or (3) absent due to larval supply. Bugula and Schizoporella consistently settled in crevices on surfaces with roughness elements and these locations acted as spatial refuges (Tables $2 \& 3$ ). Neither consistently settled in increased numbers in pits of similar sizes (Table 3). Survival of Schizoporella was either random (surfaces with $5.0 \mathrm{~mm}$ pits $)$ or reduced in pits $(2.0 \mathrm{~mm}$ pits; Table 4$)$. Bugula did not preferentially settle in $2.0 \mathrm{~mm}$ pits and survival was lowest in this location (Tables $3 \& 4$ ).

There is evidence that larvae of all 4 species actively chose their settlement location after encountering these topographically complex surfaces placed facedown in this low-energy environment (flow rates: 0 to $15 \mathrm{~cm} \mathrm{~s}^{-1}$; Culliney 1969). We repeated settlement plate trials in different months and years and found consistent results between trials that could not be 
explained by the passive deposition model (Table 3). If larvae were deposited as passive particles, then they would have only accumulated in crevices and pits. However, on some surfaces, Bugula, Schizoporella and Tubularia settled in significantly greater numbers in areas of high erosion: the flat areas between roughness elements on Styela, the sides of roughness elements on Styela, and the rims or exposed surfaces on pitted surfaces (see Walters \& Wethey 1991 for calculations of the roughness Reynolds number, $\mathrm{Re}^{*}$, for these surfaces). Thus, we believe that larval exploration of surfaces occurred. Laboratory trials have also documented larval exploration under controlled conditions (Balanus: e.g. Crisp 1981, Mullineaux \& Butman 1991; Bugula: Woollacott 1984; Schizoporella: L.J.W. pers. obs.; Tubularia: Mills \& Strathmann 1987). Evidence for active exploration under similar field conditions for Balanus and Bugula comes from Walters (1992b). Through a series of manipulative field experiments on plates with uniformly spaced $2.0 \mathrm{~mm}$ roughness elements, it was demonstrated that larvae of both species must either crawl or tumble over surfaces before settling consistently in crevices.

Active surface exploration may explain additional selectivity by larvae of the 2 species with limited attachment, Balanus and Bugula, for crevices of medium size roughness elements on Styela. The number of settlers per plate was very similar when plates with large and small roughness elements from each trial were compared (ANOVA, p > 0.05). However, on these surfaces, larvae were only exposed to 1 size roughness element. On the surfaces of Styela, larvae potentially encountered roughness elements of many sizes. Balanus settled at the bases of roughness elements that ranged from 0.6 to $5.7 \mathrm{~mm}$ in height. Bugula settled on roughness elements that ranged from 0.6 to $8.8 \mathrm{~mm}$ high. Although the distribution of small $(\leq 2.0 \mathrm{~mm})$, medium $(2.0<x \leq 5.0 \mathrm{~mm})$, and large $(>5.0 \mathrm{~mm})$ roughness elements was similar on each Styela (L.J.W. pers. obs.), the majority of larvae settled in contact with medium size roughness elements (Table 2). Roughness elements in this size range may have marked the limits of larval exploratory ability. Alternatively, they may have been chosen to provide a spatial refuge for individuals long enough for reproduction to occur or for a size refuge to be obtained.

Potential sources of mortality included competitors, predators, and physical disturbance events. Refuges from competitors are predicted to be topographic highs (Connell \& Keough 1985, Walters \& Wethey 1991); refuges from predators and disturbances should be crevices and pits (Barry \& Dayton 1991). Competitive interactions are frequently more common with species that have unlimited attachment to the substrata (e.g. Jackson 1977, 1979). In the Pacific Northwest, the encrusting bryozoan Membranipora membrancea was frequently overgrown by competitors and it settled preferentially on topographic highs on surfaces with uniformly spaced roughness elements or pits (Walters \& Wethey 1991). However, neither Schizoporella nor Tubularia were likely to succumb to this source of mortality. Schizoporella is a dominant spatial competitor in the North Carolina system and once established, it can resist invasion of all other species (Sutherland \& Karlson 1977, Sutherland 1978). By combining rapid growth and a stolon-mat morphology, Tubularia stolons frequently overgrew other competitors and if any stolons were overgrown, death of the colony did not result (L.J.W. pers. obs.). Additionally, removal of competitors had no effect on survival for Bugula recruits that settled in all possible locations on settlement plates with uniformly spaced $2.0 \mathrm{~mm}$ roughness elements during $20 \mathrm{~d}$ trials in this habitat (Walters 1992a). The filefish Monacanthus setifer was the primary predator in this system and it consumed all individuals not in refuges (Walters 1992a). If competition is not an important source of mortality in this system, then individuals should settle in crevices or pits to reduce mortality due to fish predation and physical disturbance events.

The distribution of settlers was not influenced by the number of settlers in a trial or spatial exclusion over time. We observed significant preferences in species with high settlement (Balanus) as well as in species with low settlement (Bugula, Tubularia, Schizoporella). It is also unlikely that settlement patterns were the result of larval exclusion, based on the number of previously settled individuals in a trial. Although competitive exclusion (pre-emption) would eventually keep larvae from settling in preferred settlement locations (Wethey 1984), it was not likely in these shortterm experiments. If each settled individual was considered to occupy $1 \mathrm{~mm}^{2}$ from the day it arrived, then daily loss of space available could be calculated through the last day of the trial (Wethey 1984). During the trial with the most settlement (8669 settlers), the area remaining available for settlement at Day 7 in crevices, the consistently preferred settlement location, could be calculated. Unoccupied area in crevices decreased from $379 \mathrm{~mm}^{2}$ to $287 \pm 8 \mathrm{~mm}^{2}$ (mean $\pm \mathrm{SE}$ ) on plates with $2.0 \mathrm{~mm}$ roughness elements and from $123 \mathrm{~mm}^{2}$ to $80 \pm 11 \mathrm{~mm}^{2}$ on plates with $5.0 \mathrm{~mm}$ roughness elements. Thus, $76 \%$ of the space on plates with small roughness elements and $45 \%$ of the space on plates with large roughness elements was still available for settlement after $7 \mathrm{~d}$. Additionally, if larvae were excluded from the crevices over time, then the proportion of larvae seitiing litere sluvulu decreâse over time. On each day of the trial, the number of larvae settling in this location was compared to the total 
number of settling larvae. On the plates with $5.0 \mathrm{~mm}$ roughness elements, the proportion of larvae settling around the bases of the roughness elements remained constant throughout the trial. However, more Balanus larvae settled around the bases of small roughness elements on the last day of the trial (Day 7 ) than on Day 5 $(F=3.84 ; \mathrm{df}=5,18 ; \mathrm{p}=0.0260)$. This result is opposite the pattern expected if larvae were being excluded as space filled up.

The results of these studies are consistent with our predictions that both refuge dimensions and growth form influenced settlement and short-term post-settlement success. Because fish and disturbance events were the primary sources of mortality, pits and crevices should have provided the best refuges. However, both settlement and refuge quality were consistently greater in crevices than pits of the same magnitude. Larvae of animals with limited attachment to the substrata actively settled in refuges that covered a vory small amount of the available surface area. Larvae with these growth forms additionally chose refuges of specific sizes. Larvae of animals with unlimited growth along the substrata were less specific about attachment location and grew out of refuge locations within days. Overall, both growth form and refuge dimensions need to be carefully considered when determining refuge quality on a topographically complex surface.

Acknowledgements. J. Sutherland, S. Woodin, S. Ortega, and A. Underwood assisted with the experimental design. J. Sutherland, D. Rittschof, S. Ortega, K. Reinsel, and J. Ramus, Director, provided laboratory space, facilities, and housing at the Duke University Marine Laboratory. P. Sacks helped build the equipment. This study was supported by the University of South Carolina, and awards from the American Association of University Women, Sigma $X_{i}$, the Lerner-Gray Fund for Marine Research (American Museum of Natural History), the Houston Underwater Club, the International Womens Fishing Association, and the Association for Women in Science to L.J.W and Office of Naval Research Contract (N00014-82-K0645) and National Science Foundation Grant (OCE86-00531) to D.S.W. S. Woodin, D. Lincoln, J. Sutherland, D. Rittschof, R. Showman, and 2 anonymous reviewers greatly improved this manuscript.

\section{LITERATURE CITED}

Barry JP, Dayton PK (1991) Physical heterogeneity and the organization of marine communities. In: Kolasa J, Pickett STA (eds) Ecological heterogeneity. Springer-Verlag, New York, p 270-320

Bergeron P, Bourget E (1986) Shore topography and spatial partitioning of crevice refuges by sessile epibenthos in an. ice disturbed environment. Mar Ecol Prog Ser 28:129-145

Brawley SH, Johnson LE (1991) Survival of fucoid embryos in the intertidal zone depends upon developmental stage and microhabitat. J Phycol 27:179-186
Buss LW (1979) Group living, competition, and the evolution of cooperation in a sessile invertebrate. Science 213: $1012=1014$

Butman CA (1987) Larval settlement in soft-sediment invertebrates: the spatial scales of pattern explained by active habitat selection and the energy role of hydrodynamic processes. Oceanogr Mar Biol A Rev 25:11.3-165

Chabot R, Bourget E (1988) Influence of substratum heterogeneity and settled barnacle density on the settlement of cypris larvae. Mar Biol 97:45-56

Connell JH (1961) Effects of competition, predation by Thais lapillus, and other factors on natural populations of the barnacle Balanus balanoides. Ecol Monogr 31:61-104

Connell JH, Keough MJ (1985) Disturbance and patch dynamics of subtidal marine animals on hard substrata. In: Pickett STA, White PS (eds) Natural disturbance: the patch dynamics perspective. Academic Press, New York, p $125-151$

Crisp DJ (1981) Overview of research on marine invertebrate larvae, 1940-1980. In: Costlow JD, Tipper RC (eds) Marine biodeterioration: an interdisciplinary study. Naval Institute Press, Annapolis, MD, p 103-126

Crisp DJ, Bälles í i1954) The onentation and distribution of barnacles at settlement with particular reference to surface contour. J Anim Ecol 23:142-162

Culliney JL (1969) Larval biology and recruitment of the shipworms Terredo navalis and Bankia gouldi in the Newport Estuary, N.C. PhD dissertation, Duke University Durham, NC

Dean TA (1981) Structural aspects of sessile invertebrates as organizing forces in an estuarine fouling community. J Exp Mar Biol Ecol 53:163-180

Grosberg RK (1981) Competitive ability influences habitat choice in marine environments. Nature 290:700-702

Harvey M, Bourget E, Ingram RG (1995) Experimental evidence of passive accumulation of marine bivalve larvae on filamentous epibenthic structures. Limnol Oceanogr 40 94-104

Havenhand JN, Svane [ (1991) Roles of hydrodynamics and larval behavior in determining spatial aggregation in the tunicate Ciona intestinalis. Mar Ecol Prog Ser 68:271-276

Hay ME, Paul VJ, Lewis SM, Gustafson $K$, Tucker J, Trindell RN (1.988) Can tropical seaweeds reduce herbivory by growing at night? Diel patterns of growth., nitrogen content, herbivory, and chemical versus morphological defenses. Oecologia 75:233-245

Jackson JBC (1977) Competition on marine hard substrata: the adaptive significance of solitary and colonial strategies. Am Nat 111:743-767

Jackson JBC (1979) Morphological strategies of sessile animals. In: Larwood $G$, Rosen BR (eds) Biology and systematics of colonial organisms. Academic Press, New York, p 499-555

Jackson JBC, Hughes TP (1985) Adaptive strategies of coralreef invertebrates. Am Sci 73:265-274

Keough MJ (1986) The distribution of a bryozoan on seagrass blades: settlement, growth, and mortality. Ecology 67 846-857

Keough MJ, Downes BJ (1982) Recruitment of marine invertebrates: the role of active larval choices and early mortality. Oecologia 54:348-352

LeTourneux FE, Bourget E (1988) Importance of physical and biological settlement cues used at different spatial scales. Mar Biol 97:57-66

Lubchenco J (1983) Littoria and Fucus: effects of herbivores substratum heterogeneity, and plant escapes during succession. Ecology 64:1116-1123 
Lubchenco J, Cubit J (1980) Heteromorphic life-histories of certain marine algae as adaptations to variations in herbivory. Ecology 61:676-687

Menge BA, Lubchenco J (1981) Community organization in temperate and tropical rocky intertidal habitats: prey refuges in relation to consumer pressure gradients. Ecol Monogr 51:429-450

Middleton GV, Southward JB (1984) Mechanics of sediment movement, 2nd edn. Society of Economic Paleontologists and Mineralogists, Tulsa, OK

Miller RG (1966) Simultaneous statistical inference, 2nd edn. McGraw-Hill, New York

Mills CE, Strathmann MF (1987) Phylum Cnidaria, class Hydrozoa. In: Strathmann MF (ed) Reproduction and development of marine invertebrates of the northern Pacific coast. University of Washington Press, Seattle, p $44-71$

Mullineaux LS, Butman CA (1991) Initial contact, exploration and attachment of barnacle (Balanus amphitrite) cyprids settling in flow. Mar Biol 110:93-103

Mullineaux LS, Garland ED (1993) Larval recruitment in response to manipulated field flows. Mar Biol 116:667-683

Pawlik JR, Butman CA, Starczak VAR (1991) Hydrodynamic facilitation of gregarious settlement of a reef-building tube worm. Science 251:421-424

Raimondi PT (1990) Patterns, mechanisms, and consequences of variability in settlement and recruitment in an intertidal barnacle. Ecol Monogr 60:283-309

SAS Institute (1988) SAS user's guide: statistics, 6.04 edn. SAS Institute, Cary, NC

Shanks AL, Wright WG (1986) Adding teeth to wave action: the destructive effects of wave-borne rocks on intertidal organisms. Oecologia 69:420-428

Sutherland JP (1978) Functional roles of Schizoporella and Styela in a fouling community at Beaufort, North Carolina. Ecology 59:257-264

Sutherland JP, Karlson RH (1977) Development and stability of the fouling community at Beaufort, North Carolina. Ecol Monogr 47:425-446

Walters LJ (1991) Settlement and post-settlement success of marine invertebrates on topographically complex hard

This article was submitted to the editor substrata. PhD dissertation, University of South Carolina, Columbia

Walters LJ (1992a) Post-settlement success of the arborescent bryozoan Bugula neritina (L.): the importance of structural complexity. J Exp Mar Biol Ecol 164:55-71

Walters LJ (1992b) Field settlement locations on subtidal marine hard substrata: is active larval exploration involved? Limnol Oceanogr 37:1101-1107

Walters LJ, Wethey DS (1986) Surface topography influences competitive hierarchies on marine hard substrata: a field experiment. Biol Bull 170:441-449

Walters LJ, Wethey DS (1991) Settlement, refuges, and adult body form in colonial marine invertebrates: a field experiment. Biol Bull 180:112-118

Wethey DS (1984) Spatial patterns in barnacle settlement: day to day changes during the settlement season. J Mar Biol Ass UK 64:687-698

Wethey DS (1986) Ranking of settlement cues by barnacle larvae: influence of surface contour. Bull Mar Sci 39:393-400

Woodin SA (1974) Polychaete abundance patterns in a marine soft-sediment environment: the importance of biological interactions. Ecol Monogr 44:171-187

Woodin SA (1978) Refuges, disturbance, and community structure: a marine soft-bottom example. Ecology 59:274-284

Woodin SA (1981) Disturbance and community structure in a shallow water sand flat. Ecology 62:1052-1066

Woollacott RM (1984) Environmental factors in bryozoan settlement. In: Costlow JD, Tipper RC (eds) Marine biodeterioration: an interdisciplinary study. Naval Institute Press, Annapolis, MD, p 149-154

Young BL (1991) Spartina axil zones: preferred settlement sites of barnacles. J Exp Mar Biol Ecol 151:71-82

Young CA (1986) Defenses and refuges: alternative mechanisms of coexistence between a predatory gastropod and its ascidian prey. Mar Biol 91:513-522

Young CA, Chia FS (1981) Laboratory evidence for delay of larval settlement in response to a dominant competitor. Int J Invert Reprod 3:221-226

Young CA, Chia FS (1984) Microhabitat-associated variability in survival and growth of subtidal solitary ascidians during their first 21 days after settlement. Mar Biol 81:61-68

Manuscript first received: November 17, 1994

Revised version accepted: January 23, 1996 